\title{
THE EFFECT OF MARKET ORIENTATION, BRANDING, AND ORGANIZATION PERFORMANCE ON SMALL-SCALE BUSINESSES OF BIOTECHNOLOGY-BASED PRODUCTS IN JEMBER
}

\author{
Edy Wahyudi, Galih Wicaksono, Mohamad Dimyati, Nian Riawati \\ University of Jember \\ edydata75@gmail.com,galih.fisip@unej.ac.id,_dimyati.feb@unej.ac.id,_nian.fisip@unej.ac.id
}

\begin{abstract}
This study aims to determine market orientation, branding, and organizational performance in small businesses that produce biotechnology-based products in Jember. The object of this research is small businesses that produce biotechnology-based products in Jember Regency, taking samples of 90 small businesses. This study grapples with primary data, which is data obtained from distributing questionnaires to the small business actors. Methods of data analysis involved multiple linear regression. The research results demonstrate that market orientation and branding altogether pose a significant effect on organizational performance. Partially, it is only the branding variable which exerts a significant effect on organizational performance, while the market orientation variable has no significant effect on organizational performance.
\end{abstract}

Keywords: Market Orientation, Branding, Organizational Performance, small businesses, biotechnology

\section{Introduction}

Biotech products are actually not new in the food industry in Indonesia. If we look at it, actually what is consumed on daily basis by most people in Indonesia is biotechnology products. These products are bread, soybean cake, soy sauce, and fermented cassava. The products have been accepted by the Indonesian people and considered safe for consumption. This study will attempt to examine small-scale businesses that produce biotechnology-based products such as soybean cake, soy sauce, and fermented cassava. Previous research has never delved into small-scale business' biotechnology-based products, so the current study deems it important to probe the potential of such business for renewing body of knowledge.

The businessmen in processing biotechnology products in the form of soybean cake, soy sauce, and fermented cassava are mostly small-scale businesses managed by households. This business plays vital role in economic equality and provides large employment opportunities for the country. The roles of small-scale business' biotechnology-based products are actually multitude. First, they aid in strengthening the national economy through various business linkages such as the functions of production, distribution, marketing, and consumption for the general public. Second, these small-scale businesses are able to absorb a lot of labor, which is expected to increase the country's economic growth. Third, they also serve as a means of distribution or distribution of national income. This is because small businesses are evenly distributed from villages to cities, and remote areas are also reached by small businesses. 
The long-term focus gradually can improve performance and improve the competitiveness of small-scale businesses by taking into account market needs. Market needs or market orientations are measures of behavior and activities that reflect the implementation of marketing concept (Tjiptono et al, 2008). Market orientation is very crucial for small-scale businesses, because the businesses are able to meet consumers' needs and can compete in a wider market.

In addition to market orientation, new biotechnology product is also needed. Sustainable product innovation is a fundamental requirement which in turn will be able to bring about competitive advantage. Innovation is an important function of marketing management, because innovation will determine the sustainability of smallscale businesses. Product innovation will be increasingly important as one of the elements for survival, particularly in order to deal with uncertainty in the business environment (Wahyono, 2002). The number of businesses grappling with biotechnology products has increased competition, especially for some businesses that manufacture similar products. The increasingly fierce competition and the fact that consumers are more critical in choosing products demand small-scale businesses to be more innovative in producing goods, or in other words these businesses have to be able to offer new products that are better than the current competing products (Lapian et al., 2016).

The branding of biotechnology products is the next concern to take into account in biotechnology product businesses. Brand is one of the most important elements of a product, both products in the form of goods and services, especially biotechnology products such as soybean cake, soy sauce, and fermented cassava, which generally rarely display brands. Brands are very closely related to various corporate strategies and imply business promises to consistently provide unique characteristics, benefits, and services to consumers (Durianto et al, 2001). To date, it is still rare for small-scale business in biotechnology products to produce soybean cake, soy sauce, and soybean cake with particular attention to the brand. The products produced are often sold without any brand, but rather only sold to the market or to the final consumer. Therefore, such marketing strategy is hardly effective, which is why we need to think about specific brand attached to these biotech products.

Based on the discussion above, this study will delve into the effect of market orientation, branding, and organizational performance. The research results on market orientation by Lapian et al (2016) have found that the results of consumer experience in using certain product will result in consumer ratings of the business. In general, consumers will take into account what is obtained from existing products, judging whether the product has met their expectations or not. Furthermore, according to Pertiwi and Siswoyo (2016), small-scale businesses of biotechnology products call for the right strategy, with a focus on market orientation, created and shaped by scrutinizing customer needs, desires, and satisfaction continuously.

Research conducted by Julianto and Wahyudi (2013) in small-scale businesses has found that sustainable product innovation can be done by keeping up with market 
access and effective marketing strategies. The study also demonstrates that the strength of the business lies in the uniqueness of its product (differentiation), which also substantially determines the market response. High differentiation allows businesses to apply expensive (premium) prices to their products.

With regard to product branding, Aprilia (2016) has found that the use of brand image in products will influence consumer behavior. This can be seen from the possibility of known products, reputation, and attractiveness, allowing consumers to be more interested in biotechnology products with particular brands.

Based on several previous studies, small-scale businesses are characterized by uniqueness, research related to the marketing model, and continuous product innovation, which is also the case in small-scale businesses on biotech products. Problems in improving the marketing model and product innovation will always remain dynamic, especially because consumer needs are constantly changing and developing. What is more, market competition continues to increase, which is even tougher due to the development of information technology. Simply put, market competition is worth further study. The aforementioned elaboration backgrounds the current study to delve into small-scale businesses with specific focus on those producing biotechnology products.

This study will identify market orientation in small-scale business biotechnology products, by looking at business trends, customer, and internal company competitors. Aspects of product innovation will see trends in innovation made on biotechnology products, innovation in processes, and administration innovation. The aspect of branding deals with the extent to which small businesses of biotechnology products consider the urgency of branding. Based on these aspects, it is expected to find out whether there is an influence of market orientation, branding, and organizational performance.

This research was conducted in Jember. The city was chosen to be research site because based on the observations of researchers it had a number of small-scale businesses and there were numerous small-scale businesses ranging from bread, soy sauce, soybean cake, and fermented cassava. Furthermore, Jember had a superior product in the form of fermented cassava. The other small-scale businesses, such as soybean cake, can reach every sub-district in the city.

\section{The Problem Scope of Small-Scale Businesses}

The crisis that has taken place in Indonesia has raised the awareness that small-scale business sector has a very important role in strengthening the structure of the national economy. The importance of small-scale business sector is not only to strengthen the national industry, but also because it relates to the lives of most Indonesian people. The small business sector has a large role in the overall economic development of the nation. In 1998 (post-crisis), the number of small and medium enterprises (SMEs) reached $99.8 \%$ of our total economic players, while the rest, only $0.2 \%$, were large business actors. This shows that the majority of our 
economic actors are small and medium enterprises. This sector also absorbs $88.3 \%$ of the total Indonesian workforce. All existing small business units, reaching $54 \%$ of the total businesses, are involved in agricultural sector. Also, 23\% in the trade sector and $10.6 \%$ are processed industrial business units. This fact shows the importance of empowering small-scale businesses in Indonesia (Karjantoro, 2002)

\subsection{Market Orientation}

Market orientation focuses on expansion, giving more attention to customers and competitors (Kohli and Jaworski, 1990; Kotler and Armstrong, 1994; Narver and Slater, 1998). In general, there is a consensus that market orientation reflects the needs of organizations to be market-oriented or market-driven in nature (Deng and Dart, 1994; Hurley and Hult, 1998; Jaworski and Kohli, 1996; Slater and Narver, 1995). Lafferty and Hult (2001) point out that there are four different approaches in the concept of market orientation, including:

1) Decision making perspective

2) Market intelligence perspective

3) Cultural-based behavioral perspective

4) Strategic perspective

5) Customer orientation perspective (customer orientation perspective)

This study applies market orientation variables with a behavioral approach proposed by Narver and Slater (1990), which is closer to the concept of customer orientation, competitor orientation, and functional coordination in its market orientation.

\subsection{Branding}

Wheeler (2009) posits that brand identity is a form and entity in our mind. It can be seen, touched, held, heard, and seen in motion. Brand identity is a source of introduction, shows differences, and makes big opinions as well as meanings or a product. Keller (2013) explains that a company image will depend on several factors, such as the products a company makes, the measures taken by a company, and the behavior in communicating it to consumers. There are several different types of associations linked to a company brand and can affect brand equity, which include the following.

1. The attributes, benefits, or nature of the product, such as individual brands. In this regard, a company brand generates strong associations in product attributes for consumers.

2. People and their relationships. The corporate image association is likely to reflect the characteristics of employees or employees of the company.

3. Value and program. Corporate image associations also reflect company values and programs that are not always directly related to its product.

4. Company credibility.

An important part of brand association is the company credibility. The credibility ensures consumers' trust in the company, indicating the extent to which it 
can design and deliver products and services that meet consumers' needs and desires. Consumers who award brands as credibility will usually consider and choose brands that have high and strong credibility, indicating that the product also offer other additional benefits.

\section{Research Method}

This study examined the effect of market orientation and branding on organization performance. The population of this study was small-scale businesses on biotechnology products in Jember Regency. The sample was determined by using accidental sampling method. Therefore, anyone who was considered appropriate and accidentally available during the study was involved as research subjects. The sampling covered 90 small businesses. The analysis steps in the study are as follow.

1) Descriptive Statistics

Descriptive statistics in research are basically the process of transforming research data in the form of tabulations that present summaries, measurements, or compilation of data in the form of numerical tables and graphs. Such process aims to generate clear data interpretation (Indriantoro and Supomo, 2002:170). The purpose of descriptive statistics is to find out a general description of the research data and the relationships that exist between the variables under investigation.

2) Instrument Test

a. Validity test. This aims at investigating the level of reliability and validity of measuring instruments. The instrument is said to be valid when it can be used to measure what should be measured (Sugiyono, 2011).

b. Reliability test. This test intends to investigate the questionnaire, particularly its accuracy in terms of variable or construct under investigation. A questionnaire is said to be reliable if a person's answer to a statement is consistent or stable over time. Reliability also involves consistency of answers, tested repeatedly in different samples.

3) Test of Classical Assumptions

To find out whether the regression model really shows a significant relationship and representative or called BLUE (Best Linear Unbiased Estimator), then the model has to meet the classic assumptions of regression. The classic assumptions tested in this study are normality, multicollinearity and heteroscedasticity.

4) Hypothesis Testing

a. Multi-linear Analysis

This study applied multi-linear regression analysis to examine the effect of independent variables on the dependent variable. The regression equation used is as follow.

$\mathrm{Y}_{\mathrm{ROA}}=\mathrm{a}+\mathrm{b}_{1} \mathrm{X}_{1}+\mathrm{b}_{2} \mathrm{X}_{2}+\mathrm{e}$

Let:

$\mathrm{Y}=$ Organization performance 


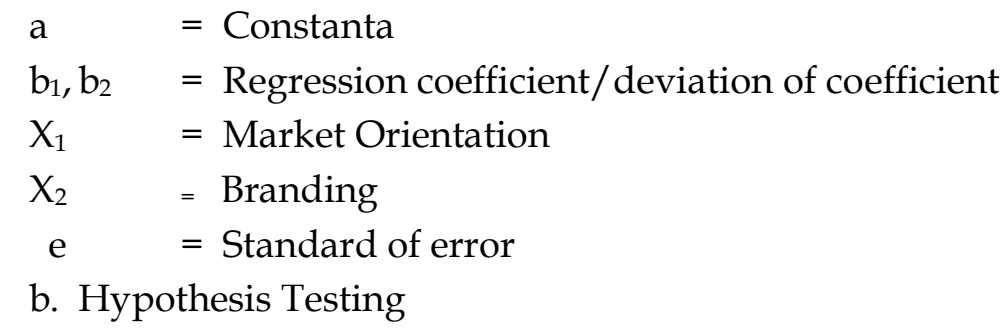

Hypothesis testing used in this study is only a partial regression test. Partial tests are conducted to determine whether the independent variables contained in the regression equation individually affect the value of the dependent variable.

The testing steps are as follows:

- Hereunder are the criteria in determining the hypothesis test

○ Ho : $b_{i}=0$; (the regression coefficient is equal to zero, meaning that independent variable pose insignificant influence on dependent variable).

- $\mathrm{Ha}: \mathrm{b}_{\mathrm{i}} \neq 0$; (the regression coefficient is not zero, meaning that independent variable pose significant influence on dependent variable).

Let $\mathrm{i}=1,2, \ldots, 6$

If Sig. $>$ a, Ho is approved

If Sig. $<a$, Ho is rejected

- Expected significance level is $a=5 \%$ or confidence level reaches $95 \%$.

- Drawing conclusion

\section{Results of Statistical Test}

Based on the results of reliability testing, the study shows that all questions are reliable, indicating that they can be used for further analysis. In addition, validity test also stipulates that all questionnaire questions are proven valid and thus can be used for further testing.

Respondents in this study were small-scale businessmen focusing on producing biotechnology-based products in Jember Regency. 90 questionnaires were distributed to small-scale businessmen. After all the questionnaires were filled out, then the researcher recapped the data into Ms. Excel format. After the data was complete, then the classical assumption test was carried out. Based on the normality test of the data, all data were normally distributed and there were no deviations identified, so the data collected can be processed with the following methods. The analysis results have demonstrated that the data is in the same direction and spread around the diagonal line. Based on multicollinearity test, all research variables produce tolerance values above 0.1 and VIF values below 10. Thus, there is no linear relationship between independent variables or multicollinearity in each variable. The last classic assumption test is heteroscedasticity test, which has shown that there is no clear pattern formation, and points spread above and below the number 0 on the $\mathrm{Y}$ axis. As a corollary, heteroscedasticity does not occur. 
After passing the classical assumption, the data were regressed to SPSS-aided analysis. The following is the results of partial and simultaneous test on the relationship of each research variable.

Tabel 1. The Results of Linear Regression Test

Coefficients $^{\mathrm{a}}$

\begin{tabular}{|c|c|c|c|c|c|c|}
\hline & \multirow[t]{2}{*}{ Model } & \multicolumn{2}{|c|}{$\begin{array}{l}\text { Unstandardized } \\
\text { Coefficients }\end{array}$} & \multirow{2}{*}{$\begin{array}{c}\begin{array}{c}\text { Standardized } \\
\text { Coefficients }\end{array} \\
\text { Beta }\end{array}$} & \multirow[t]{2}{*}{$\mathrm{t}$} & \multirow[t]{2}{*}{ Sig. } \\
\hline & & B & Std. Error & & & \\
\hline \multirow{4}{*}{1} & (Constant) & 1,017 & 1,155 & & 881 & ,381 \\
\hline & Market & - 084 & , 056 & ,119 & 1,505 & 136 \\
\hline & Orientation & & & & & \\
\hline & Branding & ,801 & ,084 & ,753 & 9,538 & ,000 \\
\hline
\end{tabular}

a. Dependent Variable: Organization Performance

Source: Research Data (2018)

Based on the results of SPS-aided analysis, the market orientation has a significance level (sig. T) of 0.136, where the value is greater than a (0.05). Therefore, $\mathrm{H} 0$ is accepted, while H1 is turned down, which means that the market orientation does not significantly influence organization performance. Furthermore, the study has revealed that branding e has a significance level (sig. T) of 0,000 . This value is smaller than a (0.05), so H0 is rejected, while $\mathrm{H} 2$ is accepted. This means that branding has a significant effect on Organizational Performance.

Table 2. The Results of Multi-linear Regression Test

ANOVA $^{a}$

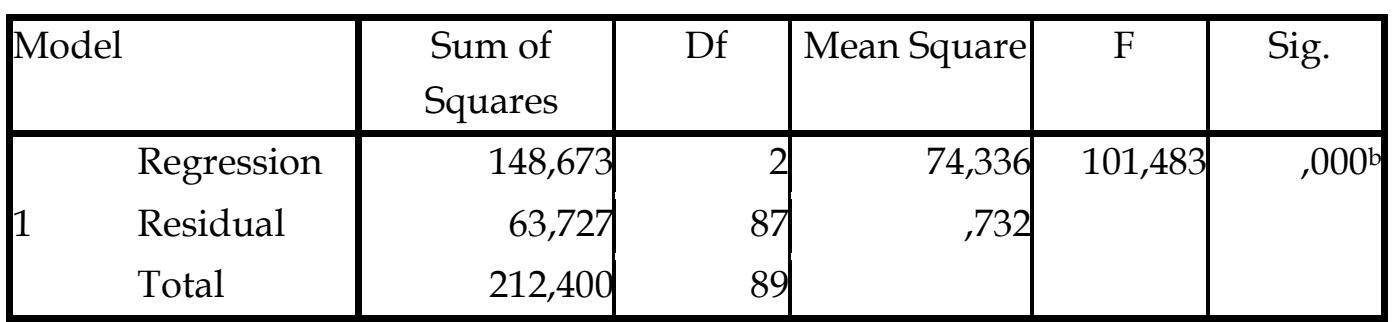

a. Dependent Variable: Organization Performance

b. Predictors: (Constant), Branding, Market Orientation

Source: Research Data (2018)

Based on the results of multi-linear regression analysis, it can be seen that the correlation between the independent and significant dependent variables is marked by a value of 0.00 , meaning that the number is below the threshold of significance value, which is 0.05 . Therefore, the study has concluded that the independent variables influence the dependent variables, meaning that branding and market orientation altogether pose a significant effect on organization performance.

After analyzing the results of $\mathrm{T}$ Test and $\mathrm{F}$ Test, the determination coefficient value (R2) can commence, the result of which shows the influence level of independent variable on the dependent variable. Coefficient of 0 means that there is no effect of 
independent variables on the dependent variable. By contrast, if the coefficient value is getting closer to 1 or 100 percent, this means that the independent variables affect the dependent variable.

Table 3. Coefficient Determination Model Summary ${ }^{\mathrm{b}}$

\begin{tabular}{|l|r|r|r|r|}
\hline Model & R & R Square & $\begin{array}{c}\text { Adjusted R } \\
\text { Square }\end{array}$ & $\begin{array}{r}\text { Std. Error of } \\
\text { the Estimate }\end{array}$ \\
\hline 1 &, $837 \mathrm{a}$ &, 700 &, 693 &, 856 \\
\hline
\end{tabular}

a. Predictors: (Constant), Branding, Market Orientation

b. Dependent Variable: Organization Performance

Source: Research Data (2018)

As seen in the table above, the value of R Square (R2) is 0.693 or $69.3 \%$. This shows that $69.3 \%$ of changes that occur in organization performance can be explained by independent variables comprising of market orientation and branding, while the rest $(100 \%-69.3 \%=30.7 \%)$ is under the impact of extraneous variables.

\section{Discussion}

\subsection{The Effect of Market Orientation on Organization Performance (Proven Insignificant)}

Based on the research results, market orientation has no significant effect on organization performance. This indicates that market orientation indicators that include the collection of market intelligence, the spread of market intelligence, the design of responses, and implementation of responses do not contribute to organization performance significantly. The indicators of response implementation get the lowest value, compared to other indicators in market orientation. This indicates that business actors do not quickly respond to product changes, and nor do competitors carry out intensive promotions. This is also supported by the fact that business actors often ignore complaints from customers where respondents' answers indicate unsatisfactory performance or service.

\subsection{The Effect of Branding on Organization Performance (Proven Significant)}

Based on the results of research, branding has a significant effect on organization performance. As shown by analysis results, even though this hypothesis is accepted, the data shows that the characteristics of respondents who do not name their business with a particular brand are very high, marked at $46 \%$. This indicates that businessmen assume that branding is important, but most of them do not pay attention to it. Based on the research results, in fact many small-scale business actors, especially those producing soybean cake, do not name or give a brand to their products. This indicates that, based on the perceptions of the respondents in this study, branding will have an impact on business performance. Maintaining company's image, maintaining reputation, and introducing brands to a broader marketing area will surely pose an impact on organization performance. Other findings also demonstrate that, with 
regard to respondents' perceptions and product branding, paying attention to product quality and putting emphasis on security as well as the performance of each product marketed will exert significant impact on the performance. Significant negative results are also evident because $46 \%$ of business actors do not carry out product branding. Therefore, they do not include halal labels in their products. Other data also shows that in respondents' perceptions, efforts to pay attention to product names to be remembered by consumers, making environmentally friendly packaging and paying attention to product expiration dates are not considered important by business actors. This data further clarifies that although branding has a significant influence on performance, only few business actors provide halal labels, including expiration dates, and pay attention to the packaging in their products.

\subsection{Interesting Empirical Findings}

Some interesting facts from this study are the rejection of the first hypothesis in this study. Market orientation is proven to have a insignificant impact on organization performance. This is interesting because, in general, the results of research related to market orientation always indicate that market orientation poses a significant impact on organization performance, regardless of varied values. However, if the researcher looks closely, market orientation has higher correlation value toward organization performance, particularly when relationship and branding are taken into account. This finding has confirmed that in the context of this research, market orientation will make a significant contribution and give a higher value to organization performance when businesses pay attention to branding. Interestingly, the effect of branding on performance, despite being shown to have a significant effect, has not been significant regardless of the fact that $46 \%$ of the respondents do not name their business brand. This means that they realize the importance of branding, but they do not put emphasis on it.

\section{Conclusions and Suggestions}

\subsection{Conclusion}

Based on the results of analysis and discussion, the study has concluded that the market orientation and branding altogether exert a significant effect on organization performance in small-scale businesses based on biotech products in Jember regency. However, when viewed partially, only branding has a significant effect on organization performance. As such, branding in small-scale business on biotechnology products will increase the level of organization performance. By contrast, if branding level is low, the level of organization performance will decline.

\subsection{Suggestions}

Based on the research results and discussion aforementioned, the researcher gives several suggestions as follows.

First, it is imperative that the Department of Cooperative and small-scale businesses in Jember regency disseminate the importance of product branding. Thus, 
that can increase the knowledge of small-scale business actors about the importance of product branding. This is the case as the study has found that high level of branding will improve organization performance.

Second, for the future researchers interested in investigating the performance of small-scale business, delving into other variables that have been proven to affect the level of performance, such as Marketing Mix, Innovation, and Competitive Strategy, is highly suggested. In addition, future researchers can expand the research site, for example in the ex-residency area of Besuki or even in East Java Province. This expansion will allow future researchers to generalize their findings for the development of science.

\section{REFERENCES}

Ghozali, Imam. 2018. Aplikasi Analisis Multivariate dengan program SPSS. Semarang.

Indriantoro, Nur dan Supomo, 2002, " Metodologi Penelitian Bisnis Untuk. Akuntansi dan Manajemen, Edisi Pertama, Yogyakarta : BPFE

Hurley, R. and Hutt, G.T. 1998. Innovation, Market Orientation, and Organizational Learning: An Integration and Empirical Examination. Journal of Marketing, 62 (July), 42-54

Jaworski, B.J. and Kohli, A.K. 1993. Marketing orientation: antecedents and consequences. Journal of Marketing, Vol. 57, July, pp. 53-70

Karjantoro, H. 2002. Usaha Kecil dan Problem Pemberdayaannya. Jakarta, Usahawan, No.04. th XXXI

Keller, Kevin Lane. 2013. Strategic Brand Management Building Measuring and Managing Brand Equity $4^{\text {th }}$ Edition. USA: Pearson Education

Kohli, A.K. and Jaworski, B.J. 1990. Market orientation: the construct, research propositions and managerial implications. Journal of Marketing, Vol. 54, April, pp. 1-18

Kotler, Philip and G. Armstrong. 1997. Dasar-dasar Pemasaran. Terjemah oleh Adi Zakaria, Jilid 2. CV Intermedia. Jakarta

Narver, J.C. and Slater, S.F. 1998. Additional thoughts on the measurement of market orientation: a comment on Deshpande and Fairley. Journal of Market Focused Management, Vol. 2, pp. 23-36.

Sugiyono. 2011. Metode Penelitian Kuantitatif Kualitatif dan R\&D. Bandung: CV Alfabeta

Wheeler, Alina. 2009. Brand Designing Identity. New Jersey: John Wiley\&Sons Inc. 